Eur. J. Clin. Chem. Clin. Biochem.

Vo1. 30, 1992, pp. $837-845$

(C) 1992 Walter de Gruyter \& Co.

Berlin · New York

\title{
Quantitative Determination of Natriuretic Peptides in Human Biological Samples with a Bioassay Using Cultured Cells ${ }^{1}$
}

\author{
By K. P. Kohse, K. Feifel and H. Wisser \\ Abt. für Klinische Chemie, Robert-Bosch-Krankenhaus Stuttgart, Bundesrepublik Deutschland
}

(Received March 9/September 14, 1992)

\begin{abstract}
Summary: Up to now, members of the natriuretic peptide family have usually been determined by radioimmunoassays using antibodies more or less specific for the distinct peptides so far identified. However, natriuretic peptides differing significantly in their amino acid sequence from the one against which the antibody has been raised cannot be determined by this means, and still unknown natriuretic peptides cannot be detected. We therefore developed a new bioassay system sensitive to all members of the natriuretic peptide family by taking advantage of the biological activity of these hormones, the activation of the guanylate cyclase/cyclic GMP system. In this assay, cultured cells are incubated with the natriuretic peptides, and the amount of cyclic GMP produced by the cells is determined by radioimmunoassay. From the relative stimulation of the cellular cyclic GMP production, the concentration of natriuretic peptides in the sample is determined after calibration with synthetic atrial natriuretic peptide. For a qualitative identification of the various peptides, the bioassay is combined with a reversed-phase HPLC step. Using cultured bovine aortic endothelial or bovine kidney epithelial cells for the bioassay, we achieved detection limits of $1 \mathrm{fmol}$ or $50 \mathrm{fmol}$, respectively, for human atrial as well as brain natriuretic peptide. Intra-assay coefficients of variation of $4.3 \%$ (aortic endothelial cells, at $0.65 \mathrm{nmol} / \mathrm{l}$ peptide) and $5.8 \%$ (kidney epithelial cells, at $6.5 \mathrm{nmol} / \mathrm{l}$ peptide) were obtained. The total content of natriuretic peptides as well as the amounts of the individual natriuretic peptides following HPLC separation were determined in extracts of human atria obtained at aortocoronary bypass operations. Tissue concentration values from 1.2 to $4.3 \mathrm{nmol}$ peptide per gram wet weight were obtained, which corresponded well with values determined by radioimmunoassays for human atrial and brain natriuretic peptide, thus proving our method to be suitable for the detection of natriuretic peptides in biological samples.
\end{abstract}

\section{Introduction}

Natriuretic peptides form a family of hormones which actively participate in the regulation of water and salt balance in the mammalian organism. The potent and rapid natriuretic and diuretic effect of crude rat atrial extract was first demonstrated by de Bold (1) in 1981, who thereby proved a humoral factor to be responsible for the stimulation of the kidney by volume expansion sensed in the atrium of the heart. Subsequent purification led to the identification of atrial natriuretic peptide $(2,3)$. The circulating form of

\footnotetext{
1) This work was supported by the Robert-Bosch-Stiftung, Stuttgart (Germany), and the Deutsche Forschungsgemeinschaft (Ko 969/2-1) which is gratefully acknowledged.
}

atrial natriuretic peptide consists of 28 amino acids $(4,5)$ which is derived from a 126 -residue precursor peptide (3) stored in dense secretory granules in the cardiac atrium. The peptide shows a variety of humoral actions resulting in a reduction of blood pressure and blood volume (for review, see 1.c. (6)). It interacts with the renin-angiotensin system by inhibition of renin release, vasopressin release and aldosterone synthesis and stimulates natriuresis and diuresis. While these effects of atrial natriuretic peptide are now relatively clear, receptors for the peptide are found in various regions of the organism - for example in the small intestine, the ciliary body of the eye, platelets, placenta, and the central nervous system - where their function is not yet fully understood. 
Three different natriuretic peptides encoded by separate genes have been identified: atrial natriuretic peptide, brain natriuretic peptide (7), and, most recently, cardiac or C-type natriuretic peptide (8). Furthermore, urodilatin, an $\mathrm{N}$-terminally extended atrial natriuretic peptide variant, which is thought to be produced in the kidney, has been isolated from urine (9). The atrial natriuretic peptide shows very high amino acid sequence homology throughout different mammalian species (10). The human, bovine and canine peptides are completely identical, and the mouse, rat and rabbit peptides differ only in position 110 , which is isoleucine instead of methionine. Thus, most atrial natriuretic peptides of different species can be measured in a radioimmunoassay using the same antibody (11). For the brain natriuretic peptide, however, marked interspecies sequence differences have been found. Thus, using the antibody generated against the porcine peptide (which was discovered first), no cross-reacting peptide could be detected in the human organism. A specific antibody against synthetic human brain natriuretic peptide, based on the putative amino acid sequence of this peptide, derived from a cDNA, had to be designed, which delayed the actual detection of the human peptide. As an alternative to the radioimmunoassay, a tedious physiological assay system was also available, based on the smooth muscle relaxing activity of the natriuretic peptides (12). However, even in this assay system, significant differences between the activity of the various natriuretic peptides were found (7).

Therefore, we designed a bioassay for the determination of all members of the natriuretic peptide family, taking advantage of the common molecular mechanism of action of these peptides, i. e., the activation of the guanylate cyclase-/cyclic GMP system (13). In this report, we show that the bioassay yields reliable and precise results which compare well with data obtained by the classical radioimmunoassay methods. Part of the data has been presented at the Annual Meeting of the German Society for Clinical Chemistry, and has been published in abstract form (14).

\section{Materials and Methods}

\section{Materials}

Synthetic porcine brain natriuretic peptide, human atrial natriuretic peptide $(99-126)$, and human brain natriuretic peptide $(77-108)$ as well as their ${ }^{125}$ I-labelled analogues, the antibodies against all three peptides, normal rabbit serum and goat antirabbit IgG were purchased from Peninsula Laboratories, Belmont, CA (USA). In some cases, ${ }^{125}$ I-labelled porcine brain natriuretic peptide and ${ }^{125} \mathrm{I}$-labelled human atrial natriuretic peptide were also prepared in our laboratory according to the Iodogen method (15). Cyclic guanosine $3^{\prime}: 5^{\prime}$-monophosphate, insulin and 3-isobutyl-1-methylxanthine were from Sigma, St.
Louis, MO (USA). The ${ }^{125}$ I-labelled tracer for the cyclic GMP radioimmunoassay was prepared from (2'O-monosuccinylguanosine $3^{\prime}: 5^{\prime}$ cyclic monophosphate tyrosylmethylester, Sigma) with ${ }^{125}$ I-sodium iodide (Amersham, Braunschweig, Germany) using the chloramine $\mathrm{T}$ method. The rabbit anticyclic GMP serum was a generous gift of Dr. F. Murad, Depts. of Medicine and Pharmacology, Stanford University, Stanford, CA (USA).

Dulbecco's modified Eagle's medium, pre-mixed Dulbecco's modified Eagle's/Ham's F 12 medium, foetal calf serum, penicillin/streptomycin and glutamine were purchased from Gibco BRL/Life Technologies, Eggenstein (Germany). Tissue culture dishes and bottles were from Falcon/Becton-Dickinson, Heidelberg (Germany), and Sep-Pak $\mathrm{C}_{18}$-cartridges from Millipore/ Waters, Eschborn (Germany).

Bovine kidney epithelial cells (MDBK; CCL 22; frozen) were obtained from American Type Culture Collection, Rockville, MD (USA). A frozen stock culture of bovine aortic endothelial cells, cloned originally from a primary culture (16), was kindly provided by Dr. U. Förstermann, Cardiovascular Research Area, Abbott Laboratories, Abbott Park, IL (USA).

\section{Methods}

\section{Cell culture conditions}

Bovine kidney epithelial cells were maintained in Dulbecco's modified Eagle's Medium/Ham's F 12 (1:1), $7.5 \mathrm{mmol} / \mathrm{l}$ hydroxyethyl-piperazinyl-sulphonate $(\mathrm{pH} 7.4)$ containing 0.10 $1 / 1$ foetal calf serum, $25 \mathrm{kU} / 1$ penicillin, $25 \mathrm{kU} / 1$ streptomycin, and $5 \mathrm{mg} / \mathrm{l}$ insulin. Bovine aortic endothelial cells were cultured in Dulbecco's modified Eagle's medium containing $0.10 \mathrm{l} / \mathrm{l}$ foetal calf serum, $2 \mathrm{mmol} / 1$ glutamine, $25 \mathrm{kU} / 1$ penicillin and $25 \mathrm{kU} / 1$ streptomycin. Cells were maintained at $37^{\circ} \mathrm{C}$ in $5 \% \mathrm{CO}_{2}$ and $80 \%$ relative humidity.

Frozen cell stock suspensions (ca. $1-2 \times 10^{6}$ cells) were rapidly thawed, washed twice with the respective serum-free culture medium and dispensed into $25 \mathrm{~cm}^{2}$ culture flasks. The cells usually became adherent within a day, their morphology was checked daily and medium was changed every third day. After 7 to 10 days, when confluence was reached, the cells were removed for passage by treatment with EDTA/trypsin (final concentrations, $10 \mathrm{~g} / 1$ and $2.5 \mathrm{~g} / \mathrm{l}$, respectively) for $2-5 \mathrm{~min}$, washed twice, diluted 5 -fold and dispensed into $150 \mathrm{~cm}^{2}$ flaks. Multiwell plates were inoculated using the same procedure. About 7 days later, these were used for the bioassays as described below. Within a given batch of multiwell plates, the cellular content of the wells varied by $10 \%$ at most.

\section{Bioassay for determination of natriuretic peptides}

Cells grown to confluence in 6-well (or 24-well) multiwell plates were washed twice with $2 \mathrm{ml}(1 \mathrm{ml})$ serum-free Dulbecco's modified Eagle's medium, $10 \mathrm{mmol} / 1$ hydroxyethylpiperazinyl sulphonate ( $\mathrm{pH} 7.3$ ), and preincubated at $37^{\circ} \mathrm{C}$ for $10 \mathrm{~min}$ with $990 \mu \mathrm{l}$ Dulbecco's modified Eagle's medium containing 0.5 $\mathrm{mmol} / \mathrm{l}$ isobutylmethylxanthine. Ten microlitres of peptide solution (in $1 \mathrm{~g} / 1$ bacitracin) were added and the cultures were incubated for $5 \mathrm{~min}$. The medium was aspirated, and $750 \mu \mathrm{l}$ of cold trichloroacetic acid $(60 \mathrm{~g} / 1)$ were added to the plates. The cellular extracts were centrifuged for $20 \mathrm{~min}$ at $2000 \mathrm{~g}$ and the supernatant extracted with water-saturated ether. Cyclic GMP was determined by radioimmunoassay as described below.

\section{Radioimmunoassay for cyclic GMP (17)}

All samples, standards and tracer were diluted in $50 \mathrm{mmol} / \mathrm{l}$ sodium acetate buffer, $\mathrm{pH} 4.0$, to the desired concentration. Sample or standard $(50 \mu \mathrm{l})$ was added to $150 \mu \mathrm{l}$ acetate buffer. 
After the addition of $100 \mu \mathrm{l}$ cyclic GMP tracer and $100 \mu \mathrm{l}$ rabbit anti-cyclic GMP IgG (diluted ca. 10000 fold in the above buffer with $0.1 \mathrm{~g} / \mathrm{l}$ bovine serum albumin), the tubes were vortexed and incubated overnight at $4{ }^{\circ} \mathrm{C}$. The immune complexes formed were precipitated by adding $50 \mu$ l bovine $\gamma$ globulin $(1 \mathrm{~g} / \mathrm{l})$ and $2 \mathrm{ml}$ cold 2-propanol. After centrifugation for $30 \mathrm{~min}$ at $2000 \mathrm{~g}$, the radioactivity of the pellet was determined in a model LB 2104 gamma counter (Berthold Laboratories, Wildbad, Germany).

\section{Acetylation procedure for the cyclic GMP RIA}

Sample or standard $(500 \mu \mathrm{l})$ in $50 \mathrm{mmol} / \mathrm{l}$ sodium acetate buffer ( $\mathrm{pH} 4.0$ ) was pipetted into glass tubes, followed by $20 \mu$ triethylamine. The tubes were vigorously vortexed, $10 \mu l$ acetic anhydride were added and the tubes were again vortexed. Only $2-3$ samples should be treated at the same time. The acetylated samples or standards may be stored for $2-3$ days at $4{ }^{\circ} \mathrm{C}$ or at $-20^{\circ} \mathrm{C}$ for several weeks.

Radioimmunoassay for human atrial, human brain, and porcine brain natriuretic peptides

For the radioimmunoassays for all three peptides, we followed the procedure recommended by the manufacturer (Peninsula Laboratories). In brief, a two-day protocol with sequential addition of ${ }^{125}$ I-labelled tracer and antibody was used; the separation of bound and free radioactivity was achieved by precipitation with goat anti-rabbit globulin.

\section{Tissue extraction}

Atrial appendices, which were routinely dissected for cannulation of the vena cava during the extracorporeal circulation procedure in cardiac operations, were placed into liquid nitrogen immediately after removal and stored at $-70^{\circ} \mathrm{C}$ until use. The frozen tissue was cut into small pieces which were boiled in $0.1 \mathrm{~mol} / 1 \mathrm{HCl}(1 \mathrm{ml} / 100 \mathrm{mg}$ tissue, or at least $2 \mathrm{ml})$ for 10 min to inactivate intrinsic proteases and then homogenized with a Polytron mixer. The homogenates were centrifuged at $3000 \mathrm{~g}$ for $60 \mathrm{~min}$ and the supernatant was diluted with 1 volume of $1 \mathrm{ml} / 1$ trifluoroacetic acid and filtered. These tissue extracts were loaded onto pre-conditioned Sep-Pak $\mathrm{C}_{18}$ cartridges which were then washed with $1 \mathrm{ml} / \mathrm{l}$ trifluoroacetic acid. The peptides were eluted with $2 \mathrm{ml} 0.80 \mathrm{l} / 1 \mathrm{CH}_{3} \mathrm{CN}$ containing $1 \mathrm{ml} / \mathrm{l}$ trifluoroacetic acid. The eluates were dried in a vacuum centrifuge (Speed-Vac, Savant, Farmingdale, NY, USA), stored at $-20^{\circ} \mathrm{C}$ and dissolved in the appropriate buffer before use.

\section{High-performance liquid chromatography analysis}

A reversed-phase chromatography system on a $\mathrm{C}_{18}$ silica gel column (Spherisorb ODS II, $3 \mu \mathrm{m} ; 4.6 \times 125 \mathrm{~mm}$; Bischoff, Leonberg, Germany) was used with a binary solvent system: solvent A, $1 \mathrm{ml} / 1$ trifluoroacetic acid, $0.2 \mathrm{l} / 1$ acetonitrile; solvent $\mathrm{B}, 1 \mathrm{ml} / 1$ trifluoroacetic acid, $0.6 \mathrm{l} / 1$ acetonitrile. After injection of the sample, a linear gradient from solvent A to solvent B in $15 \mathrm{~min}$ at an elution rate of $1 \mathrm{ml} / \mathrm{min}$ was applied, followed by a plateau of $5 \mathrm{~min}$ solvent $\mathrm{B}$ before re-equilibration of the column in solvent A. The absorbance of the eluate at $210 \mathrm{~nm}$ was monitored using a Merck-Hitachi model $655 \mathrm{~A}$ variable wavelength detector.

\section{Results}

Having previously tested several different types of cultured cells for their suitability as a detection system for natriuretic peptides, we finally concentrated our work on two cell lines in which the cyclic GMP production was already known to be stimulated by atrial natriuretic peptide $(13,18)$, i. e., bovine kidney epithelial cells and bovine aortic endothelial cells. Following incubation of these adherent cells with natriuretic peptides at increasing concentrations, the intracellular concentration of cyclic GMP was determined.

\section{Assay for natriuretic peptides using kidney} epithelial cells

As shown in figure 1, the cyclic GMP system of kidney epithelial cells was equally sensitive to human atrial and brain natriuretic peptides. The stimulation of the cyclic GMP production started at a peptide concentration of less than $0.10 \mathrm{nmol} / 1$ of either human atrial or human brain natriuretic peptide, and reached saturation at about $100 \mathrm{nmol} / \mathrm{l}$ peptide. The cellular concentration of cyclic GMP increased from a basal value of ca. $1 \mathrm{pmol} /$ well to a maximum of ca. $12-15$ pmol/well. The cultured kidney epithelial cells are slightly less sensitive to porcine brain natriuretic peptide (by a factor of 2; not shown).

The performance characteristics of the assay using the cultured kidney epithelial cells are represented in table 1 showing a detection limit of $50 \mathrm{fmol}$ human atrial or brain natriuretic peptide and a variation coefficient of $4.3 \%$ at an analyte concentration of $6.5 \mathrm{nmol} / \mathrm{l}$ peptide $(n=15)$.

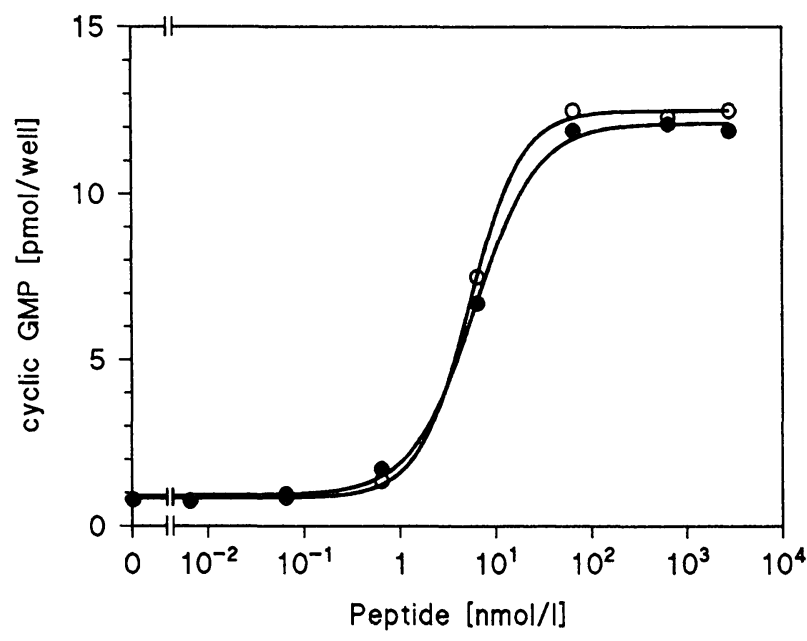

Fig. 1. Calibration curve for the bioassay for the determination of natriuretic peptides using cultured bovine kidney epithelial cells. After incubation of the cells with natriuretic peptides, the cellular cyclic GMP content was determined by radioimmunoassay, as described in the Methods section.

Closed circles: human atrial natriuretic peptide; open circles; human brain natriuretic peptide. One well in the multi-well dish contained ca. $5 \times 10^{6}$ cells. Each point represents the mean result of a duplicate analysis. 
Tab. 1. Performance characteristics of the bioassay for the determination of natriuretic peptides using the two different cultured cells lines. The stimulation of the cyclic GMP production in bovine kidney epithelial or aortic endothelial cells by the natriuretic peptides was determined as described under Methods. (n. d.: not determined)

\begin{tabular}{lll}
\hline Quantity & $\begin{array}{l}\text { Kidney } \\
\text { epithelial cells }\end{array}$ & $\begin{array}{l}\text { Aortic } \\
\text { endothelial cells }\end{array}$ \\
\hline Range of stimulation & $0.1-100 \mathrm{nmol} / 1$ & $0.001-100 \mathrm{nmol} / 1$ \\
Maximal stimulation & 12 -fold & 250 -fold \\
Detection limit & $50 \mathrm{fmol}$ & $1 \mathrm{fmol}$ \\
$\mathrm{CV}_{\text {intra-assay }}$ & $4.3 \%$ & $5.8 \%$ \\
$\quad(\mathrm{n}=15) ;$ at & $6.5 \mathrm{nmol} / 1$ & $0.65 \mathrm{nmol} / 1$ \\
$\mathrm{CV}_{\text {inter-assay }}$ & n.d. & $9.4 \%$ \\
$\quad(\mathrm{n}=8) ;$ at & - & $0.65 \mathrm{nmol} / 1$ \\
\hline
\end{tabular}

Comparative studies in 6-well culture plates $\left(9.1 \mathrm{~cm}^{2} /\right.$ well) and 24-well plates $\left(1.8 \mathrm{~cm}^{2} /\right.$ well) showed that the sensitivity of the assay for natriuretic peptides was significantly lower in 24-well plates (by a factor of 10) than in the larger wells. In the former wells, a significant stimulation of the guanylate cyclase system was observed only at concentrations of atrial natriuretic peptide exceeding $1 \mathrm{nmol} / \mathrm{l}$.

\section{Assay for natriuretic peptides using aortic end othelial cells}

Cyclic GMP production by cultured bovine aortic endothelial cells was stimulated by concentrations of human atrial or brain natriuretic peptide greater than

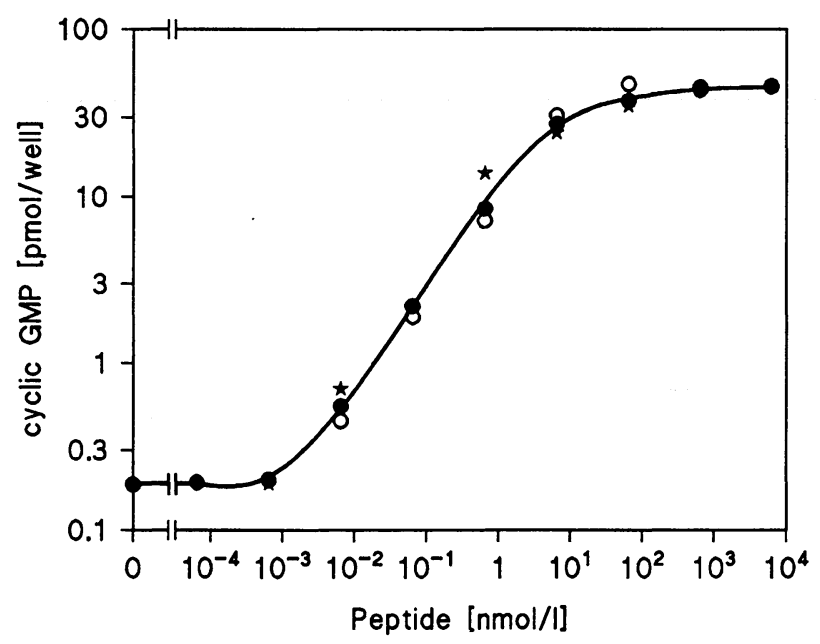

Fig. 2. Calibration curve for the bioassay for the determination of natriuretic peptides (closed circles: human atrial natriuretic peptide; open circles: human brain natriuretic peptide; asterisks: porcine brain natriuretic peptide) using cultured bovine aortic endothelial cells as described in the Methods section. One well in the multi-well dish contained ca. $4 \times 10^{5}$ cells. ca. $10^{-3} \mathrm{nmol} / \mathrm{l}$. A maximal, 250-fold stimulation occurred in response to a peptide concentration of ca. $100 \mathrm{nmol} / \mathrm{l}$, which represented saturation (fig. 2). These cells show both a lower basal cyclic GMP concentration (ca. $0.2 \mathrm{pmol} /$ well) and a higher maximal cellular cyclic GMP content following the stimulation (ca. $50 \mathrm{pmol} / \mathrm{well}$ ) than the kidney epithelial cells. Thus, the dynamic range of the assay system using the aortic endothelial cells is higher. A detection limit of $1 \mathrm{fmol}$ and an intra-assay variation coefficient of $5.8 \%$ at a peptide concentration of $0.65 \mathrm{nmol} / \mathrm{l}$ further demonstrate the higher sensitivity of the bioassay using these cells (tab. 1). The inter-assay coefficient of variation was $9.4 \%$ at $0.65 \mathrm{nmol} / 1$ peptide.

\section{Extrusion of cyclic GMP}

Egress of cyclic GMP from the cytosol into the extracellular medium was monitored over a period of 120 minutes and found to be negligible during the first 30 minutes. The concentration of cyclic GMP accumulated in the medium within this period of time did not exceed the extracellular basal value of ca. 90 fmol/well (fig. 3).

Combination of bioassay and high-performance liquid chromatography

For a qualitative identification of the individual natriuretic peptides, we coupled the bioassay with a high-performance liquid chromatography step on a reversed-phase silica gel column. Synthetic human atrial natriuretic peptide, human brain natriuretic

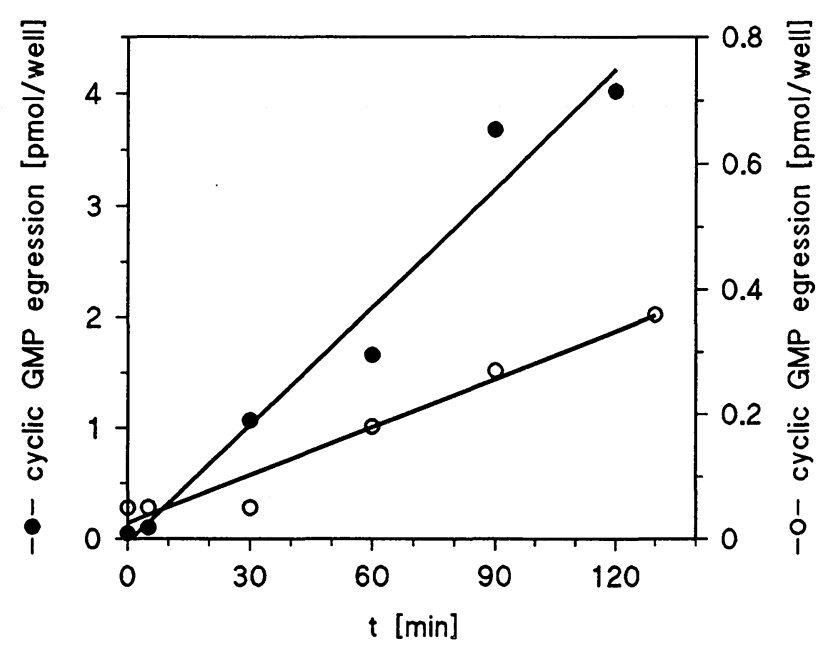

Fig. 3. Time course of the egress of cyclic GMP from cultured bovine kidney epithelial (open circles) and aortic endothelial (closed circles) cells after stimulation with 10 nmol/1 human atrial natriuretic peptide. The cell densities per well were $5 \times 10^{5}$ cells for the kidney epithelial cells and $1 \times 10^{5}$ cells for the aortic endothelial cells. 
eptide and porcine brain natriuretic peptide were :pplied separately to the HPLC column and identified in the eluate by their individual retention times as nonitored by their UV absorbance at $210 \mathrm{~nm}$. The iuman atrial natriuretic peptide, human brain natrirretic peptide and porcine brain natriuretic peptide luted at ca. $12.9 \mathrm{ml}, 10.3 \mathrm{ml}$, and $14.9 \mathrm{ml}$, respecively, the values differing slightly from column to :olumn.

$\downarrow$ mixture of all three peptides was chromatographed, he eluate was collected in fractions, and these fracions were subjected to the bioassay for natriuretic reptides using cultured bovine aortic endothelial cells.
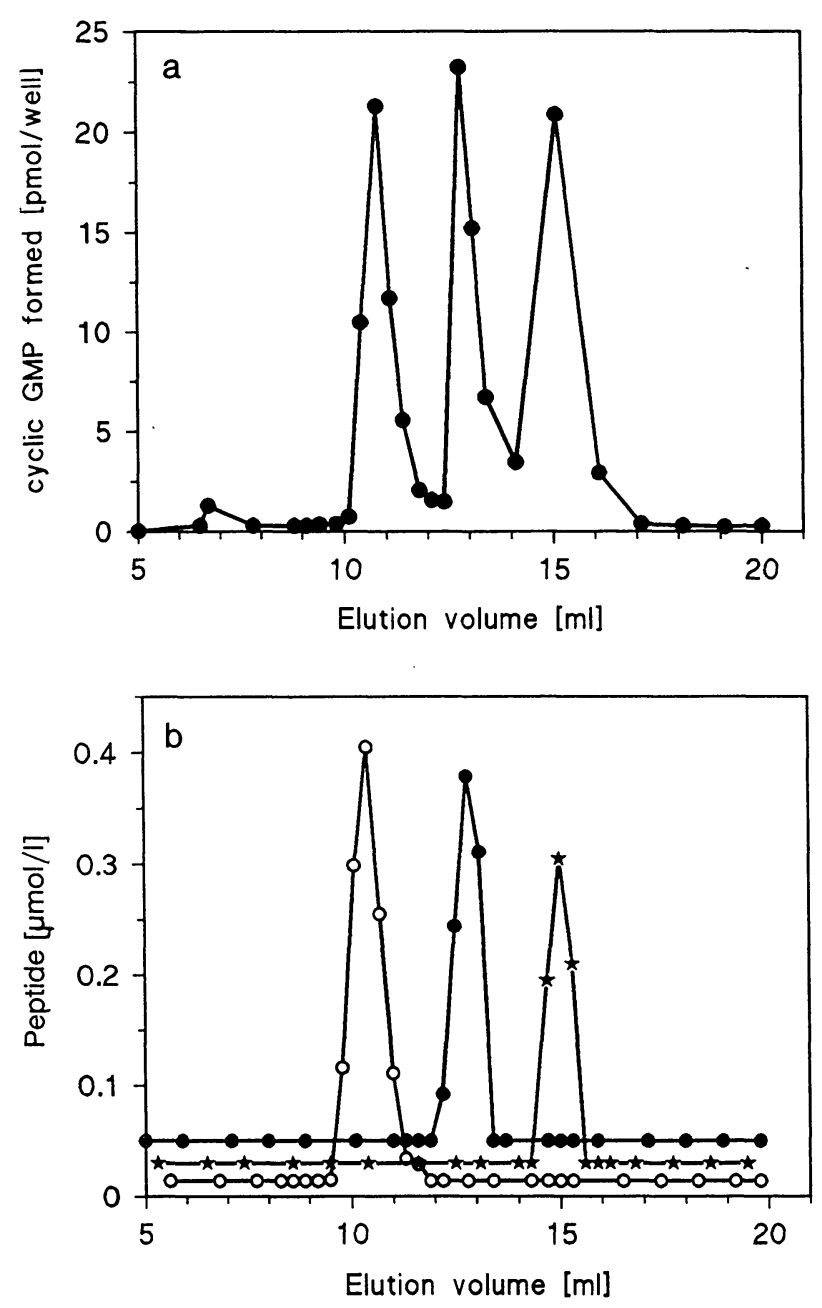

Fig. 4. Elution profile of natriuretic peptides in the reversedphase high-performance liquid chromatographic analysis. A mixture of synthetic human atrial natriuretic peptide, human brain natriuretic peptide, and porcine brain natriuretic peptide ( $400 \mathrm{pmol}$ of each peptide) was chromatographed on a $\mathrm{C}_{18}$-silica gel column, as described under Methods.

a) Determination of total natriuretic peptides in the fractionated eluate with the bioassay using bovine aortic endothelial cells.

b) Determination of human atrial (๑) and brain (o) natriuretic peptide as well as porcine brain natriuretic peptide $(\star)$ by the respective radioimmunoassays.
Figure 4a shows the resulting stimulation of the cellular cyclic GMP production by the natriuretic peptides contained in the various fractions of the elution profile. The elution volumes of the three signal peaks obtained by the bioassay corresponded closely to those observed by simultaneous UV absorbance monitoring (not shown).

In order to further verify the elution volumes with another independent method, we investigated the same high-performance liquid chromatographic fractions in separate radioimmunoassays for human atrial, human brain, and porcine brain natriuretic peptide. Figure $4 \mathrm{~b}$ represents the elution profile with the peptide concentration values determined by these radioimmunoassays. The respective signals were observed in the same fractions as those of the bioassay and the resulting peaks corresponded to those of the elution profile obtained using the bioassay, without significant deviation.

Analysis of a human cardiac extract by the high-performance liquid chromatography/ bioassay combination

The results of the bioassays performed with the fractionated eluate of a HPLC separation of an extract prepared from a human atrial biopsy are shown in figure 5. At the retention times previously found for the atrial as well as the brain natriuretic peptide, separate peaks were clearly distinguishable. The maximum of the cellular cyclic GMP production was

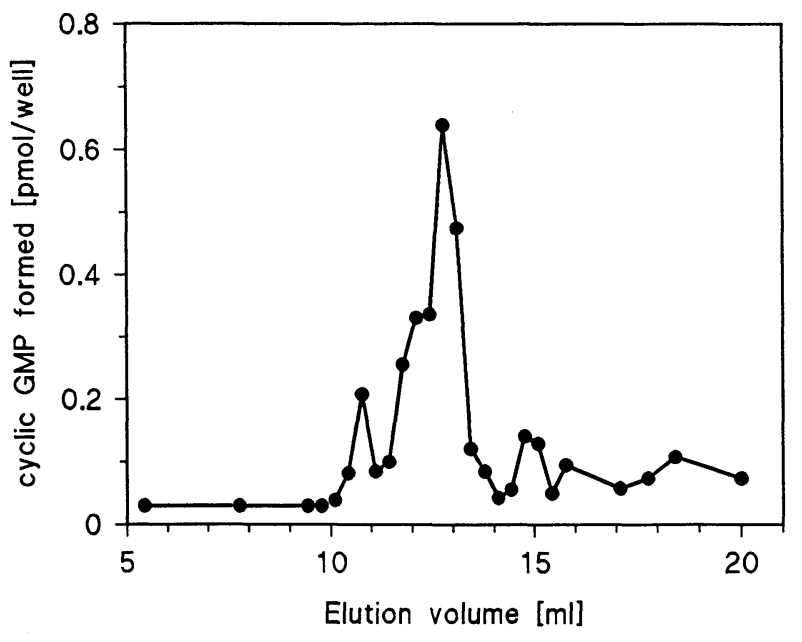

Fig. 5. Reversed-phase high-performance liquid chromatographic elution profile of natriuretic peptides from human cardiac tissue. Peptides were extracted from part of the atrial appendix dissected during aortocoronary bypass surgery as described in the Methods section. The extract was chromatographed on a $\mathrm{C}_{18}$-silica gel column, and the natriuretic peptides in the fractionated eluate were detected with the bioassay using bovine aortic endothelial cells, as described under Methods. 
observed at an elution volume of ca. $13 \mathrm{ml}$ which corresponds to that of the synthetic atrial peptide. A smaller peak eluted at ca. $10.7 \mathrm{ml}$, the elution volume for synthetic brain natriuretic peptide. However, minor amounts of guanylate cyclase-stimulating substances were also eluted from the column after the atrial peptide.

Comparison of natriuretic peptide concentrations determined by bioassay with those obtained by radioimmunoassay

In a first application of the bioassay to the analysis of biological samples, we determined the content of natriuretic peptides in extracts of human cardiac atria routinely dissected in heart surgery procedures. Amounts of total natriuretic peptide in these samples between 1.2 and $4.3 \mathrm{nmol} / \mathrm{g}$ tissue (wet weight) were found. In the same tissue samples, concentrations of human atrial and brain natriuretic peptide were measured separately using specific radioimmunoassays. Comparison of the results obtained by the two different assay systems (tab. 2) shows that the total natriuretic peptide concentration, expressed as the sum of the tissue levels of atrial and brain natriuretic peptides determined by radioimmunoassay, differs only marginally from the values obtained by using the bioassay (maximal deviation, $18 \%$; mean, $7.4 \%$ ). The radioimmunoassay gave a mean natriuretic peptide concentration of $3.0 \mathrm{nmol} / \mathrm{g}$ tissue, whereas 2.8 $\mathrm{nmol} / \mathrm{g}$ were found with the bioassay using the cultured bovine aortic endothelial cells.

When the bioassay was combined with HPLC, the cumulative sum of the masses of the different peptides (obtained from the calibration curve of the bioassay) also compared well with the value obtained by the

Tab. 2. Total concentration of natriuretic peptides in human cardiac atria obtained during open heart surgery. Concentrations were determined either by the bioassay using bovine aortic endothelial cells or by radioimmunoassays for human atrial or brain natriuretic peptide, as described in the Methods section. Additionally, the relative difference between the values obtained by the two methods is given $(100 \%=$ radioimmunoassay values).

\begin{tabular}{|c|c|c|c|c|c|}
\hline \multirow{3}{*}{$\begin{array}{l}\text { Patient } \\
\text { No. }\end{array}$} & \multicolumn{5}{|c|}{ Natriuretic peptides (nmol/g) } \\
\hline & \multirow[t]{2}{*}{ Bioassay } & \multicolumn{3}{|c|}{ Radioimmunoassay } & \multirow{2}{*}{$\begin{array}{l}\text { Differ- } \\
\text { ence } \\
(\%)\end{array}$} \\
\hline & & sum & atrial & brain & \\
\hline P 8 & 1.24 & 1.52 & 1.48 & 0.039 & 18 \\
\hline P 9 & 3.32 & 3.70 & 3.64 & 0.060 & 10 \\
\hline $\mathrm{P} 12$ & 1.59 & 1.66 & 1.66 & 0.001 & 4 \\
\hline P 13 & 4.29 & 4.44 & 4.40 & 0.042 & 3 \\
\hline P 23 & 3.51 & 3.43 & 3.39 & 0.036 & 2 \\
\hline
\end{tabular}

radioimmunoassay. The brain natriuretic peptide peak contained $0.08 \mathrm{nmol} / \mathrm{g}$ tissue, and the atrial natriuretic peptide peak contained $1.10 \mathrm{nmol} / \mathrm{g}$ tissue $(1.3 \mathrm{nmol} / \mathrm{g}$ as determined by radioimmunoassay; $\mathrm{cf}$. also tab. 2).

\section{Discussion}

When this work was started, it was not known whether a human equivalent of the natriuretic peptide isolated from porcine brain (7) existed. Using antibodies against the porcine peptide and a ${ }^{125}$ I-labelled porcine brain natriuretic peptide tracer, we were unable to detect any cross-reacting substance in human plasma (unpublished observations). This indicated a significant difference between the amino acid sequences of the porcine and the putative human brain natriuretic peptide. Even though a cDNA for the human peptide was cloned, antibodies against human brain natriuretic peptide were not yet available.

The purpose of our study was to develop an assay system sensitive to all kinds of natriuretic peptides regardless of their origin and their individual amino acid sequence. A possible approach was to take advantage of the biological activity of the hormone family, since all known natriuretic peptides share the same molecular mechanism of action via a receptormediated process. These peptides activate the membrane-bound form of the enzyme, guanylate cyclase, which releases intracellular cyclic GMP $(13,18-23)$. Apart from the heat-stable toxin of Escherichia coli (24), natriuretic peptides are the only known compounds to activate particulate guanylate cyclase; therefore, the stimulation of this enzyme-receptor complex is a specific signal for the presence of natriuretic peptides in samples of mammalian origin.

Besides the laborious smooth muscle-relaxing bioassay for natriuretic peptides (12), another method for the determination of these peptides had been described which is not based on an immunological principle. Ballermann (25) used rat kidney glomerular membrane preparations for a sensitive radioreceptor assay. However, the vast majority of binding sites for natriuretic peptides in kidney membranes are C-type receptors (26) not coupled to particulate guanylate cyclase, which means that natriuretic peptides may differ in their binding characteristics to this receptor (27), leading to different sensitivities of the assay for various natriuretic peptides. Furthermore, the radioreceptor assay may also detect biologically inactive degradation products of atrial natriuretic peptide. Additionally, the concentration of the receptor protein itself in the assay seems to be of critical importance 
(25), and last but not least, the assay requires the periodic sacrifice of experimental animals.

It is surprising that the various peptides investigated in this study showed similar efficiencies in the stimulation of the cyclic GMP system. Using amino- or carboxyterminally truncated atrial natriuretic peptide analogues (which are unphysiological), e. g., atriopeptins I, II, and III, Leitman \& Murad (28) found different $\mathrm{EC}_{50}$ values for the elevation of the cellular concentration of cylic GMP in bovine aortic endothelial cells. These cells were almost 1000 times less sensitive to atriopeptin I (which lacks the last 3 carboxyterminal amino acids) than to the physiological human atrial natriuretic peptide. Thus, it may be speculated that atrial and brain natriuretic peptides are equally effective in controlling the regulatory functions of endothelial cells in vivo.

In our study, we used two different cultured cell lines for the development of a bioassay for the determination of natriuretic peptides. When comparing the relative merits of the bovine kidney epthelial and aortic endothelial cells, several aspects have to be considered. While the cultured bovine kidney epithelial cells are easy to handle and commercially available, the culture of the bovine aortic endothelial cells is more difficult, requiring a thorough control of the morphology of the cells. On the other hand, the cyclic GMP system of the latter cells shows a much higher sensitivity to both human atrial and brain natriuretic peptides than that of the kidney epithelial cells. The detection limit of the bioassay using the bovine aortic endothelial cells was in the same order of magnitude as that of the radioimmunoassays for atrial $(0.3 \mathrm{fmol})$ or brain $(1 \mathrm{fmol})$ natriuretic peptide. However, the low basal cellular concentrations of cyclic GMP in the aortic endothelial cells can be reliably determined by the radioimmunoassay only after acetylation of the samples, as the cyclic GMP assay using nonacetylated samples is not sensitive enough. This sample preparation step is not necessary with the kidney epithelial cell assay. Thus, the assay using kidney epithelial cells may be useful for screening purposes in samples with relatively high concentrations of natriuretic peptides, while the aortic endothelial cell line should be used whenever a high sensitivity is required.

Cyclic GMP was monitored in the surrounding medium, because it was conceivable that significant quantities of the cyclic nucleotide generated following the stimulation of the membrane-bound guanylate cyclase could be lost from the cells. This would decrease the sensitivity of the assay, because the medium is aspirated off the cells before the determination of cellular cyclic GMP. However, the extrusion process seems to be too slow to interfere with the determination of the cellular cyclic GMP content. Compared with the basal or natriuretic peptide-stimulated cellular content of cyclic GMP, the amount released during the first 3 minutes of incubation with the natriuretic peptides can be ignored. Similar results have also been obtained by Hamet et al. (29) who showed that the egress of cyclic GMP in bovine aortic endothelial cells, following a stimulation of the synthesis by $0.1 \mu \mathrm{mol} / 1$ atrial natriuretic peptide, is slow in onset.

Since the activation of the guanylate cyclase/cyclic GMP system is the common feature of all natriuretic peptides $(13,18,23)$, the bioassay using cultured cells does not distinguish between different natriuretic peptides in biological samples. As shown in this study, cultured bovine kidney epithelial and aortic endothelial cells are equally sensitive to both human atrial and brain natriuretic peptide. At a given concentration, different peptides produce the same rise in the concentration of intracellular cyclic GMP. Though it is theoretically conceivable that other, not yet discovered members of the natriuretic peptide family in man or other species may lead to higher or lower cellular cyclic GMP concentrations than atrial or brain natriuretic peptide, or that they may show different efficiencies in the stimulation of the cyclic GMP system, these differences are not sufficient for a definite qualitative identification of these peptides. This identification is achieved by the addition of the "second dimension" to our assay system, the chromatographic step. Our data show that the different natriuretic peptides known so far are reliably recognized and quantitatively determined by the combination of the bioassay with the high-performance liquid chromatography separation, even in biological samples.

The data obtained with human cardiac atria using the specific radioimmunoassays for human atrial and brain natriuretic peptides confirm the results of the bioassay for all natriuretic peptides investigated. The absolute concentrations of natriuretic peptides determined in this study were in the same order of magnitude as those reported by others. However, we found somewhat lower concentrations of atrial as well as brain natriuretic peptides in the atria of our patients than Mukoyama et al. (30). The mean atrial tissue levels of atrial and brain natriuretic peptides in their report were $9.6 \mathrm{nmol} / \mathrm{g}$, and $250 \mathrm{pmol} / \mathrm{g}$, respectively. In contrast to these authors who investigated heart tissue obtained at autopsies, we used only small pieces of atrial appendages obtained during cardiac surgery. Regional differences in the tissue distribution may account for the lower natriuretic peptide concentrations reported by us. 
Compared with the specific radioimmunoassays for the respective natriuretic peptides, the advantage of the bioassay presented in this report is that it detects all members of the natriuretic peptide family. However, the versatility of this method also constitutes its disadvantage, in that the specific identification of a particular natriuretic peptide requires the high-performance liquid chromatography separation step. As a consequence, the procedure becomes somewhat lengthy and more laborious. However, for the analysis of tissues or other biological samples where it has been established previously that only one member of the natriuretic peptide family is present, fractionation by high-performance liquid chromatography should not be necessary. This approach could also be adopted for the determination of a particular member of the natriuretic peptide family which is present in great excess over the other natriuretic peptides in the sample to be analysed.

In conclusion, we have shown that the bioassay using cultured bovine kidney epithelial or aortic endothelial cells with or without the reversed-phase high-performance liquid chromatography step represents a method which is well suited for the quantitative and qualitative analysis of natriuretic peptides in biological samples. However, the assay, especially in combination with the chromatographic procedure, is not intended for a routine clinical diagnostic use but rather for special investigations or research purposes.

\section{References}

1. de Bold, A. J., Borenstein, H. B., Veres, A. T. \& Sonnenberg, H. (1981) A rapid and potent natriuretic response to intravenous injection of atrial myocardial extracts in rats. Life Sci. 28, 89-94.

2. Cantin, M. \& Genest, J. (1985) The heart and the atrial natriuretic factor. Endocrinol. Rev. 6, 107-127.

3. Kangawa, K. \& Matsuo, H. (1984) Purification and complete amino acid sequence of $\alpha$-human atrial natriuretic polypeptide. Biochem. Biophys. Res. Commun. 118, $131-$ 139.

4. Seidman, C. E., Bloch, K. D., Klein, K. A., Smith, J. A. \& Seidman, J. G. (1984) Nucleotide sequences of the human and mouse atrial natriuretic factor genes. Science 226, $1206-1209$.

5. Thibault, G., Lazure, C., Schiffrin, E. L., Gutkowska, J., Chartier, L., Garcia, R., Seidah, N. G., Chrétien, M., Genest, J. \& Cantin, M. (1985) Identification of a biologically active circulating form of rat atrial natriuretic factor. Biochem. Biophys. Res. Commun. 130, 981-986.

6. Struthers, A. D. (ed.) (1990) Atrial Natriuretic Factor, Blackwell Scientific Publications, Oxford.

7. Sudoh, T., Kangawa, K., Minamino, N. \& Matsuo, H. (1988) A new natriuretic peptide in porcine brain. Nature $332,78-81$.

8. Sudoh, T., Minamino, N., Kangawa, K. \& Matsuo, H. (1990) C-type natriuretic peptide (CNP): A new member of natriuretic peptide family identified in porcine brain. Biochem. Biophys. Res. Commun. 168, 863-870.

9. Schulz-Knappe, P., Forssmann, K., Herbst, F., Hock, D., Pipkorn, R. \& Forssmann, W. G. (1988) Isolation and structural analysis of "urodilatin", a new peptide of the cardiodilatin-(ANP)-family, extracted from human urine. Klin. Wochenschr. 66, 752-759.

10. Inagami, T. (1989) Atrial natriuretic factor (Minireview). J. Biol. Chem. 264, 3043-3046.

11. Nakao, K., Sugawara, A., Morii, N., Sakamoto, M., Suda, M., Soneda, J., Ban, T., Kihara, M., Yamori, Y., Shimokura, M., Kiso, Y. \& Imura, H. (1984) Radioimmunoassay for $\alpha$-human and rat atrial natriuretic polypeptide. Biochem. Biophys. Res. Commun. 124, 815-821.

12. Currie, M. G., Geller, D. M., Cole, B. R., Siegel, N. R., Fok, K. F., Adams, S. P., Eulanks, S. R., Galluppi, G. R. \& Needleman, P. (1983) Bioactive cardiac substances: potent vasorelaxant acitivity in mammalian atria. Science 221, $71-73$.

13. Song, D.-L., Kohse, K. P. \& Murad, F. (1988) Brain natriuretic factor: Augmentation of cellular GMP, activation of particulate guanylate cyclase and receptor binding. FEBS Lett. 232, 125-129.

14. Kohse, K. P., Feifel, K. \& Wisser, H. (1991) Quantitative Bestimmung von Mitgliedern aus der Familie der natriuretischen Peptide in Herzmuskelproben mit einem ZellkulturBioassay. Eur. J. Clin. Chem. Clin. Biochem. 29, 638-639.

15. Salacinski, P. R., McLean, C., Sykes, J. E., Clement-Jones, V. V. \& Lowry, P. J. (1981) Iodination of proteins, glycoproteins, and peptides using a solid-phase oxidizing agent, 1, 3, 4, 6-tetrachloro-3 alpha, 6 alpha-diphenyl glycoluril (Iodogen). Anal. Biochem. 117, 136-146.

16. Longenecker, J. P., Kilty, L. A., Ridge, J. A., Miller, D. C. \& Johnson, L. K. (1983) Proliferative variability of endothelial clones derived from adult bovine aorta: Influence of fibroblast growth factor and smooth muscle cell extracellular matrix. J. Cell. Physiol. 114, 7-15.

17. Steiner, A. L., Parker, C. W. \& Kipnis, D. M. (1972) Radioimmunoassay for cyclic nucleotides. I. Preparation of antibodies and iodinated cyclic nucleotides. J. Biol. Chem. 247, 1106-1113.

18. Leitman, D. C., Andresen, J. W., Catalano, R. M., Waldman, S. A., Tuan, J. J. \& Murad, F. (1988) Atrial natriuretic peptide binding, cross-linking, and stimulation of cyclic GMP accumulation and particulate guanylate cyclase activity in cultured cells. J. Biol. Chem. 263, 3720-3728.

19. Waldman, S. A., Rapoport, R. M. \& Murad, F. (1984) Atrial natriuretic factor selectively activates particulate guanylate cyclase and elevates cyclic GMP in rat tissues. J. Biol. Chem. 259, 14332-14334.

20. Winquist, R. J., Faison, E. P., Waldman, S. A., Schwartz, K., Murad, F. \& Rapoport, R. M. (1984) Atrial natriuretic factor elicits an endothelium-indepent relaxation and activates particulate guanylate cyclase in vascular smooth muscle. Proc. Natl. Acad. Sci. USA 81, $7661-7664$.

21. Hamet, P., Tremblay, J., Pang, S. C., Garcia, R., Thibault, G., Gutkowska, J., Cantin, M. \& Genest, J. (1984) Effect of native and synthetic atrial natriuretic factor on cyclic GMP. Biochem. Biophys. Res. Commun. 123, 515- 528.

22. Tremblay, J., Gerzer, R., Pang, S. C., Cantin, M., Genest, J. \& Hamet, P. (1985) ANF stimulation of detergent-dispersed particulate guanylate cyclase from bovine adrenal cortex. FEBS Lett. 194, 210-214. 
23. Furuya, M., Takehisa, M., Minamitake, Y., Kitajima, Y., Hayashi, Y., Ohnuma, N., Ishihara, T., Minamino, N., Kangawa, K. \& Matsuo, H. (1990) Novel natriuretic peptide, CNP, potently stimulates cyclic GMP production in rat cultured vascular smooth muscle cells. Biochem. Biophys. Res. Commun. 170, 201-208.

24. Hughes, J. M., Murad, F., Chang, B. \& Guerrant, R. L. (1978) The role of cyclic GMP in the action of heat-stable enterotoxin of Escherichia coli. Nature 271, 755-756.

25. Ballermann, B. J. (1988) A highly sensitive radioreceptor assay for atrial natriuretic peptide in rat plasma. Am. J. Physiol. 254, F159-F163.

26. Maack, T., Suzuki, M., Almeida, F. A., Nussenzveig, D., Scarborough, R. M., McEnroe, G. A. \& Lewicki, J. A. (1987) Physiological role of silent receptors of atrial natriuretic factor. Science 238, 675-678.

27. Rutherford, R. A. D., Wharton, J., Needleman, P. \& Polak, J. M. (1991) Autoradiographic discrimination of brain and atrial natriuretic peptide-binding sites in the rat kidney. $J$. Biol. Chem. 266, 5819-5826.
28. Leitman, D. C. \& Murad, F. (1986) Comparison of binding and cyclic GMP accumulation by atrial natriuretic peptides in endothelial cells. Biochim. Biophys. Acta 885, 74-79.

29. Hamet, P., Pang, S. C. \& Tremblay, J. (1989) Atrial natriuretic factor-induced egression of cyclic guanosine $3^{\prime}: 5^{\prime}$ monophosphate in cultured vascular smooth muscle and endothelial cells. J. Biol. Chem. 264, 12364-12369.

30. Mukoyama, M., Nakao, K., Hosoda, K., Suga, S.-I., Saito, Y., Ogawa, Y., Shirakami, G., Jougasaki, M., Obata, K., Yasue, H., Kambayashi, Y., Inouye, K. \& Imura, H. (1991) Brain natriuretic peptide as a novel cardiac hormone in humans. Evidence for an exquisite dual natriuretic peptide system, atrial natriuretic peptide and brain natriuretic peptide. J. Clin. Invest. 87, 1402-1412.

Dr. med. Dr. Klaus P. Kohse

Städtische Kliniken

Institut für Laboratoriumsdiagnostik

und Mikrobiologie

Dr.-Eden-Straße 10

W-2900 Oldenburg

Bundesrepublik Deutschland 
